Portland State University

PDXScholar

$1-13-1972$

\title{
The Effect of Glucose on the Food Intake of Goldthioglucose Injected Mice
}

Janet Lahti

Portland State University

Follow this and additional works at: https://pdxscholar.library.pdx.edu/open_access_etds

Part of the Biochemical Phenomena, Metabolism, and Nutrition Commons, and the Medical

Physiology Commons

Let us know how access to this document benefits you.

\section{Recommended Citation}

Lahti, Janet, "The Effect of Glucose on the Food Intake of Goldthioglucose Injected Mice" (1972).

Dissertations and Theses. Paper 1573.

https://doi.org/10.15760/etd.1571

This Thesis is brought to you for free and open access. It has been accepted for inclusion in Dissertations and Theses by an authorized administrator of PDXScholar. Please contact us if we can make this document more accessible: pdxscholar@pdx.edu. 
AN ABSTRACT OF THE THESIS OF Janet Lahti for the Master of Science in Psycholosy presented January 13, 1972.

Title: The Effect of Glucose on the Food Intake of Goldthioglucose Injected Mice

APPROVED BY NENBERS OF THE THESIS COMMITTEE:

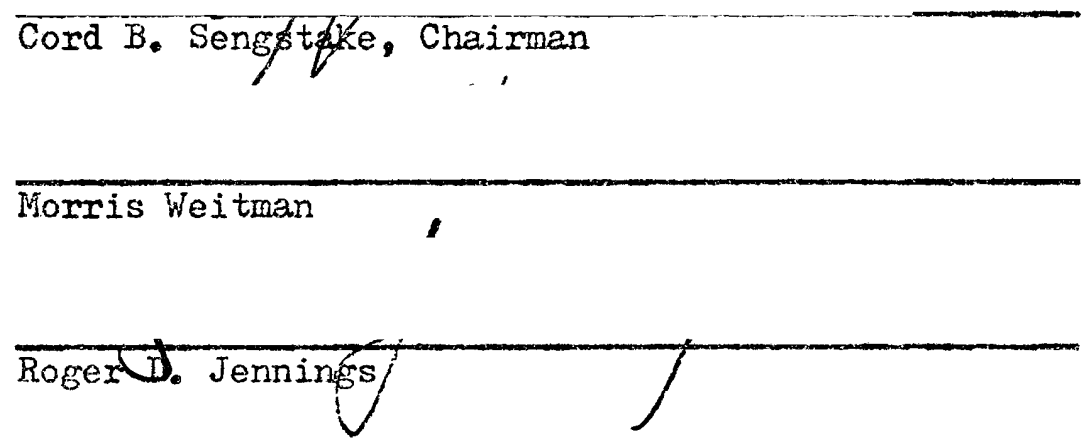

Jean Mayer has postulated the presence of giucoreceptors located primarily in the ventromedial hypothalemic nuclei of the brain which are activated by glucose in the measure that they utilize it. According to Mayer, hunger occurs when glucose is not available for metabolic purposes and satiation supervenes when glucose is made available. Control of this mechanism rests with the glucoreceptors. These receptors are believed to be destroyed when an injection of the compound goldthioglucose is given to mice. These animals subsequently become obese and axe found to have gold deposits and lesions in the ventromedial area and also in other parts of the brain.

If the gIucoreceptors are destroyed and cannot respond to the presence of glucose in the blood, it would be predicted that food intake 
would not change with the glucose level. The purpose of this investigation was to see if the food intake of goldthioglucose injected animals is affected by a glucose injection.

One hundred and twenty mice were divided into four groups. One group, the controls, received no goldthioglucose. The ather three groups received the following dosages: $.5 \mathrm{mg}$. of goldthioglucose per gram of body weight, $1.0 \mathrm{mg}$. of goldthioglucose per gram of body weight and $1.3 \mathrm{mg}$. of goldthioglucose per gram of body weight. Fifty seven days after the goldthioglucose injection a training period began in which the mice were taught to consume their entire daily food intake during a 50 minute period. Then the experimental period began during which the animals were maintained on the 23 hour and 10 minute deprivation schedule. During this period the mice vere given intraperitoneal injections of $60 \mathrm{mg}$. of glucose or normal saline on alternate days for ten days. The amount of food consumed in the 50 minutes beginning 15 minutes after the glucose or saline injection was determined.

Food intake of the goldthioglucose injected animals was not different than that of the controls under any factor of the experiment. The results do not support Mayer's idea that the glucoreceptors as he describes them are destroyed by goldthioglucose. 
THE ERTECT OP GLUCOSE ON THE FOOD INTAKE OF GOLDTHIOGLUCOSE INJECTED MTCE

$$
\text { by }
$$

JANET LAITI

$A$ thesis subnjtted in partial. furfiliment of the requirements for the degree of

\section{MASTER OA SCIEMVE}

in

PSYCHOLOGY

Poxtland State University

1972 
TO THE OFFICE OF GRADUATE STUDTES:

The members of the Committee approve the thesis of Janet Lahti presented January 13, 1972.

Cord B. Sengstake/ Chairman

Morris Weitman

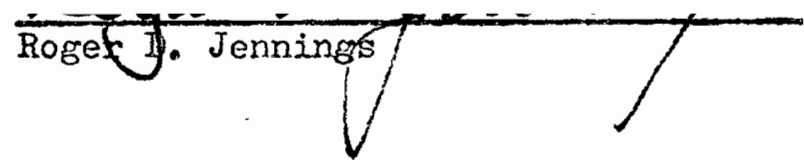

APPROVED:

Robert $\mathrm{E}_{j}$ Jones, fr., Head, Department of Psychology

David T. Clark, Dean of Graduate Studies and Research 
I INTRODUCTION ................ I 1

History ................. 1

II REVIEW OF THE IITERATURE

Ventromedial Hypothalamus .......... 4

Lateral Hypothalamus ........... 6

Hypothalamic Feeding System .......... 7

Behavioral Evidence .... . . . . . . 9

Hypothalamic Activation ........... 11

Glucostatic Theory ........... 13

Glucoreceptor Mechanism ....... 16

Goldthioglucose Induced Obesity ...... 18

III DESCRIPTION OF THE PROBLEMT $\cdot \cdot \cdot \cdot \cdot \cdot \cdot \cdot \cdot \cdot \cdot \cdot \cdot 23$

IV METHOD ................... 24

Goldthioglucose Injection ........... 24

Deprivation ............ 25

Experimental Period . . . . . . . . . 25

$\mathrm{V}$ RESTLTS ................... 28

Goldthioglucose Injection .......... 28

Experiment . . . . . . . . . . . 29 
VI DISCUSSION . . . . . . . . . . . . 34 BIBLIOGRAPHY . . . . . . . . . . . . . . . 39 


\section{ACKNOWLEDGNEATS}

Nany people have contributed in so many ways to the completion of this project. I appreciate the unwavering encouragement of $\mathrm{my}$ husband Uuno. His consistent support and that of our daughter Katherine, especially during the experimental period, made this stady possible.

Dx. C. B. Sengstake, my thesis chairman, was unfailing in his confidence in the strength of the experiment itself and in my ability to complete it. Jr. M. Weitman brought his wide experience in experimental design to bear on the problems of this experjment to assure maximum validity in the fincings. I appreciate Dr. R. D. Jennings, who as a teacher and friend, was always willing to provide valuable help and encouragement. 


\section{ISIST OF TABLES}

TABIE

PAGE

I Number of Experimental Animals . . . . . . . . . 29

II Analysis of Variance Summary Table . . . . . . . 30

III Mean Food Intake in Grams Based Upon the Dosage Isevel

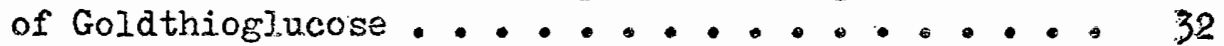

IV Mean Food Intake in Grams Based Upon the Level of Obesity ............... 32 
CHAPTER I

INTRODUCTION

Hunger and feeding are under the control of many sensory factors, both learned and unlearmed. These contribute in an additive way to the arousal of hunger and to the development of satiation: Taste, smell, gastric contractions and gastric distension, to name some major ones. Added to these are powerful influences from the more intemal environment, including both osmotic and specific chemical changes. It is the understanding of these internal physiological determinents of feeding behavior, and more specifically the influence of blood glucose on hunger and satiety which is of concerm here.

\section{HISTORY}

Before the beginning of this century explanations of the origin of hunger were largely speculative. Early in the present century, Cannon (1912) demonstrated that deprivation of food and the subjective feeling of hunger are accompanied by rhythmatic contractions of the stomach. Carlson (1916) confirmed this finding and made these gastric contractions the basis of a complete theory concerning the regulation of appetite. This theory was based on the idea that the control of food intake cests with the periphery of the body rather than with the central nervous system. With these efforts to explain empirically the mechanism of food intake, the study of hunger began in eamest. 
Experimental evidence gradually accumblated against these theories. Adolph (1947) observed that if their food is dilvted with inert material, animals quickly adjust for decreased caloric content per unit volume by consuming more of the diet. Grossman and Stein (1948) observed that denervation of the stomach in human subjects did not alter the appetite, as would have been anticipated from Carlson's theory. This kind of evidence led to the belief that the hunger mechanism was more complex than the theory of gastric contractions could explain.

A second view of the location of the physiological change which takes place to regulate food intake was advanced. This view holòs that a complex regulatory mechanism is found in the central nervous system which matches energy intake to energy expenditure. Efforts were made by investigators to define this mechanism. Attention began to focus on the hypothalamic region of the central nervous system as a possible regulatox of food intake. Hypothalamic obesity was first described by Mohr about 1840. A fifty-seven year old woman became obese within a year before her death. Autopsy showed a hypophysial tumor large enough to affect the hypothalamus (Brobeck, Tepperman and Long, 1943). A number of similar cases had already appeared when Frohlick (1902) described a syndrome with the essential features of adiposity and genital underdevelopment in patients with hypophysjal tumors. Bailey and Bremer (192l) suggested that the extreme obesity observed in patients with Frohlick syndrome was due to hypothelamic lesions and not to damage to the hypophysis. 
By the fourth decade of this century, researchers interested in the hunger mechanism had begun to focus their attention on the hypothalamic area of the brain. 


\section{CHAPTER II}

\section{RETIEW OF THE LITERATURE}

\section{VENTROMEDIAI HYPOTHALAMUS}

Improved surgical techniques enabled Hetherington and Ransom (1942) to demonstrate that, in the rat, obesity regularly follows bilateral electrolytic destruction of the ventromedial nuclei of the hypothalamus. Brobeck, Tepperman and Long (1943) obtained similar results and found obesity due almost entirely to increased food Intake and termed the syndrome hypothalamic hyperphagja. Like changes in the eating patterm have been produced experimentalis by hypothalamic lesions in many species of animals including rats (Anand and Brobeck, 1952), mice (Marshall, Barnett and Mayer, 1955), cats and monkeys (Anand, Dua and Schoenberg, 1951).

Efforts were made to describe the syndrome in detail and it was found that rats with ventromedial lesions pass through two stages, the dynamic and the static. The dynamic phase lasts approximately two months. During this time the animal displays a voracious appetite and gains weight rapidly. As the animals enter the static phase, weight increase levels off and fcod intake decreases somewhat but remains at a higher level than with normal rats.

Research has not offered an explanation for this leveling off of food intake. The hypothalamic hyperphagic rats seem to eat the same number of times as controls but they eat more at a time. Obesity is 
due primarily to increased intake and there is no major impairment of the metabolic process as a result of lesions (Killer, Bailey and Stevenson, 1950; Teitelbaum, 1955).

By implanting electrodes into the ventromedial area of rats, Kranse (1962) was able to show that stimulation of this area causes hungry rats to stop eating. .

To test the idea that the metallic deposits left by the electroIytic lesions are the cause of the obesity, Reynolds (1963) produced lesions in the ventromedial hypothalamus in two different ways, radio frequency current and electrolysis. Radio frequency lesions are produced by a surgical procedure identical to that used for electrolytic lesions except that no residual deposit of metallic ions is produced. Radio frequency destruction $\hat{x}$ ailed to produce hypothalamic hyperphagia which follows the electrolytic lesions. Reynolds believes that scar tissue produced by the electrolytic lesions may have an irritative effect on surrounding tissue. Hyperphagia arises, according to Reynolds, from the chronic imritation of the ventromedial feeding center. Reynolds (1965) produced both electrolytic lesions and radio frequency lesions in the lateral hypothalamus, the area associated with the initiation of eating. He found no difference between the two lesions in producing aphagia which usually follows lateral hypothalamic damage. From his work Reynolds concluded that cells producing a cessation of eating are located at the periphery of the ventromedial hypothalamus rather than in its center and that the area for the initiation of eating is the nucleus of the lateral area. 
Rabin (1968) investigated the electrical activity of the lateral hypothalamus in the rat following lesions of the ventromedial area. He used two kinds of lesions: the electrolytic and the radio frequency. The controls and the rats with radio frequency lesions hai electroencephlogram recordings consisting of low voltage fast activity. The EEG following electrolytic lesions consisted of a pattern of large amplitude waves. It was concluded that the data are generally consistent with the irritative hypothesis proposed by Reynolds.

Hoebel (1968) has shown that some radio frequency lesions in the ventromedial hypothalamus do, in fact, produce hyperphagia and obesity. Reynolds' irritative hypothesis is an unlikely explanation for these data since it is based on the idea that only the electrolytic lesions cause the irritation which results in obesity.

Reynolds' idea that the satiety area is on the edge of the ventromedial hypothaiamus can be questioned in view of a series of experiments by Grossman (1968) in which lesions were produced above and below as well as anterior and posterior to the feeding center. Grossman found no effect on food intake as a result of these lesions.

It is clear that electrolytic lesions in the ventromedial hypothalamus result in hyperphagia. The mechanism by which this takes place and the anatomical limits of the area are not understood. Reports concerming the radio frequency lesions seem inconclusive.

\section{IATEERAL HYPOTHALAMUS}

Further exploration of the hypothalamus led to the demonstration that an increase in eating of as much as $100 \%$ could take place in rats and cats as a result of electrical stimulation of the lateral hypothalamus 
(Delgado and Anand, 1953). The effect of this electrical stimulation resembles the hunger normally produced by deprivation of food (Coons, Levak and Miller, 1965). When the lateral area is destroyed bilaterally, complete aphagia and death due to starvation are the result in rats (Anand and Brobeck, 1952) and cats (Bach, Obrian and Cooper, 1957). A unilaterai lesion has no such effect (Anand, 1961).

The symarome resulting from lateral hypothalamic lesions hos been described by Teitelbaum and his associates (1955, 1962). Rats with lesions in the lateral hypothalamus will eventually eat and drink if they are kept alive long enough by tube feeding. Four clearmcut stages in the recovery have been described. In stage one the aninal is aphagic and adipsic and will die if not forced to consume food. During the second stage the animal will eat but not enough to maintain body weight. Rats will regulate their intake of a liquid. aiet during the third stage. They maintain their weight but are still adipsic. In the fourth stage the animal will drink water and will survive on dry food and water. In some cases there is no recovery from adipsia.

It is evident that the lateral area in some way influences the initiation of eating, since its destruction causes failure to eat and its stimulation causes overeating.

\section{HYPOTHALAMIC FEEDING SYSTEMM}

A good deal of research has been devoted to finding the possible fiber connections between the inhibitory mechanism of the ventromedial hypothalamus and the excitatory feeding center in the lateral region. 
Anand and his colleagues (1960) postulated a hypothalamic feeding system involving the ventromedial nucleus, the lateral area and nerve fibers connecting these two centers. In this system the lateral area would be the feeding center responsible for initiating the ventromedial would be the satiety center capable of exerting inhibitory control over the lateral feeding center.

Investigation of the concept that the ventromedial hypothalamic region could act as an inhibitor to the lateral hypothalamic feeding center has been conducted by several researchers.

Oomura and associates (1964) recorded spontaneous aischarges from the ventromedial nucleus and the lateral area of the hypothalamus. The activity in one area was recorded while the other was stimulated. The results revealed that significant reciprocal relations do exist.

The possible route of these anatomical connections has recently been investigated. Destruction of neurons caused their axons to degenerate, a process that is believed to occur over a period of several days. Goldthioglucose, which is believed to selectively destroy cells sensitive to blood glucose level changes, was given to mice and the degenerating axons stained by a method developed by Fink and Heimer (2967). By using this method, Aries and Mayer (1968) have found evidence for direct riber connections from the medial to the lateral hypothalamus.

Nurphy (1968) failed to find a powerful inhibitory patiway from the lateral hypothalamic area to the ventromedial hypothalamus. He suggested that one of the mechanisms by which experimental lesions or stimulation in the lateral hypothalamus influence feeding behaviour may 
be by the interruption or activation of fiber systems from other sources such as the amygdala which terminate in a converging fashion at the lateral edge of the ventromedial hypothalamus.

Sone connections appear to exist between the ventromedial hypothalamus and the lateral area. The mappine of these routes is far from complete and the manner in which they are related to the feeding system is not understood.

In summary of the evidence concerning the location of the hunger center it seems that the ventromedial area of the hypothalamus controls the cessation of eating while the lateral area controls the initiation of eating. This evidence is based on lesions produced electrolytically. Four stages have been described in the recovery from lesions in the lateral area progressing from complete aphagia to complete recovery in some cases. Hypothalamic hyperphagia, resulting from lesions in the ventromedial area, produces a djnamic phase, characterized by a voracious appetite; and a static phase, in which food intake levels off. Some connections have been found between the two areas but they are not well defined. Radio frequency lesions seem to produce a syndrome similar to electrolytic lesions in the lateral area but reports are conflicting concerming their effect on the ventromedial area.

\section{BEFAVIORAL EVIDENCE}

In ar early application of operant techniques to the study of feeding, Anliker and Mayer (1957) trained both normal mice and those made hyperphagic as a result of lesions of the ventromedial hypcthalamus to obtain food pellets by pressing a lever. Bilateral destruction of 
the ventromedial area did not result in an increase in the rate of lever pressing, a generaily reljable correlate of hunger, but hyperphagic mice spent more time pressing the lever at the same rate as the control aninals. So these hyperphagic animals were eating at a normal rate but spending more time eating than the animals who were not hyperphagic.

Miller. Bailey and Stevenson (1950) found that a decreased motivation for food in hyperphagic rats is evident rot only from a relatively low rate of bar pressing for food, but also from inferior performance on other behavioral tests. Their interpretation is that hypothalainic lesions cause the mechanism regulating hunger to stick at a relatively constant low level. While food intake remains excessive throughout the development of obesity the strength of motivation urderlying tine feeding response of the hypexphagic animal is not greater than that of a normal animal.

It appears from this research that electrolytic lesions in the ventromedial area da not increase hunger motivation but rather interfere with the mechanisn which stops eating behavior.

Teitelbaum (1955) demonstrated that the experimental animals in the initial phase of hyperphagia, like normal animals, maintain appreciable food intakes despite adulteration of their diet with cellulose or quinine, which makes it much less palatable. After becomine obese, animals show almost complete rejection of food adulterated with such substances. It appears that once the rat with ventromedial hypothalamic lesicns gets obese, he becomes a finicky eater and sensitive to the negative stimulus aspects of the diet. 
Since these hyperpharic animals are sensitive to the negative stimulus aspect of their diet, it is reasonable to question whether the type of stimulus (positive or negative) provided by taste is the basic motivational factor underlying excessive food intake which follows lesions of the ventromedial area. Teitelbaum (1963) indicates that this is not the case. When required to feed themselves by bar pressing for food ingested through permanently implanted gastric tubes, animals with ventromedial lesions eventually overeat and become obese in spite of the absence of oropharyngeal sensation. Thus it appears that excessive responsiveness to highly palatable food is not the cause of hyperphagia associated with hypothalamic lesions.

So behavioral evidence indicates that animals with ventromedial hypothalamic damage eat longer rather than faster and that responsiveness to food palatability is not the cause of obesity.

\section{HYPOTHATAMIC ACTIVATION}

After the establishment of the two hypothalamic areas as the centers for the regulation of food intake, attention was given to investigating possible explanations for the activation of these centers.

Three main theories have been advanced to account for this activation: the thermostatic, the lipostatic and the glucostatic. The lipostatic theory was proposed by Kennedy (1953, 1966) who suggested that fat stored in the body in some way regulates long term food taking perhaps through biochemical alterations which occur in the contents of its circulation as fat depots enlarge. He suggested that the animal inhibits feeding when further intake would be expected to threaten the 
fat stores. He also states that an animal begins eating when the body's metabolism threatens to take from its fat stores and an animal stops eating when additional food would add to the fat stores. Brobeck (1955, 1957, 1960) outlined the thermal hypothesis which is based on the idea that cells in the anterior hypothalamus and the preoptic area are sensitive to temperature change. It can be shown that body temperature rises after the ingestion of food, the amount of rise differing with various dietary constituents. Brobeck called this the "specific dynamic action" of a food and observed that eating is depressed by high temperatures and enhanced by low temperatures. Support for the thermostatic theory has been given by Andersson and Iarsson (1961). They found that local cooling of the preoptic area and rostral hypothalamus induces eating in the satiated goat. On the other hand, warming of the same area reduces drinking and eating. However, shirts in temperature required to obtain these effects are very large. It is possible that tempexature can affect eating and drinking but it does not seem to be the exclusive regulator. The third and the most widely investigated theory, the glucostatic, (Mayer, 1953) will be considered in more detail here. Research reported in this paper is concerned with effects of variations in blood giucose levels or food intake in animals with lesiong in the satiety area and those without. It is a test of the glucostatic theory. 


\section{GLUCOSTATIC THEORY}

In the early $1950^{\prime} \mathrm{s}$ Jean Mayer postulated the presence of chemoreceptors, located in the ventromedial hypothalamic nuclei and perhaps other central and peripheral areas as well, which have a special affinity for Elucose and are activated by this metabolite in the measure that they utilize it (Mayer, 1953). This glucostatic hypothesis was based in part on the observation that carbohydrate reserves are proportionately much more depleted between meals than are reserves of protein and fat. Mayer recognized that the regulation of food intake has both a short term and long term aspect. He suggests the glucostatic mechanism to account for short term regulation but seems to favor the lipostatic hypothesis as the basis for long tew regulation.

An effort to test this theory was made by Mayer and Von Itallie (1967). They found a correlation between overall glucose utilization, measured through arteriorenous differences in glucose concentration, and the presence or absence of gastric contractions and sensations of hunger.

Another attempt to test the relationship between gastric contractions and blood glucose levels involved the injection of the hormone glucogen which promotes both the formation of glucose, and the utilization of glucose by the cells. Injection of this hormone checked gastric contractions and reports of hunger (Stinkard, Von Itallie, Reiss, 1955). GIucogen injections over a two week period reduced significantly the amount of food eaten (Stunkard and Wolf, 1954). 
By piacing cannulas in the reins so that blood could be withdrawn at any time, Steffans (1967) demonstrated that, in an ad lib situation, blood glucose concentration rises rapidly within a few minutes after the start of a meal, whereas the between meal glucose concentration is fairly constant. The results seem compatable with the view that charges in the blood glucose level set up signals causing termination of feeding. It thus appears that the ventromedial area may exercise a measure of control over gastric hunger contractions and in response to an increase in glucose utilization. Additional evidence concerming the influence of a blood factor on food intake was demoristrated in an experiment (Davis and Miller, 1967) in which the blood of two rats, one satiated, and one deprived, was mixed 30 minutes prior to the time the deprived animal was usually fed. Immediately after this procedure, members of the pair were given access to milk for 30 minutes. Food intake of the deprived rat was reduced $50 \%$ below his normal level after the blood had been mixed. The study indicates that the blood of a satiated animal contains a factor inhibiting food intake.

To summarize the explanations for the activation of the hypothalamic area, the glucostatic, the lipostatic and the thempostatic hypotheses each offer tenable explanations for the variation in hunger. The glucostatic theory is the most widely accepted but it appears that each of these three can have some influence.

From the investigations reported above it might be concluded that the blood contains some factor ox factors important in the regulation of food intake. Evidence that this factor is glucose appears somewhat circumstantial. 
In 1964 Anand and colleagues tried to determine whether any differences in firing frequency could be detected in neurons of the satiety and feeding center as a result of procedures which alter the blood glucose level. Recordings of the unit activity from neurons of the bypothalamic feeding and satiety mechanisms and from adjacent hypothalamic regions were made in anesthetized dogs. In starved enimals the unit activity in the ventromedial hypothalamic satiety center neurons was slower than that obtained from the lateral hypothalamic feeding center neurons. Intravenous glucose and insulin or a combination of both were given and changes in spike activity noted. Frequency of spikes recorded from the satiety center neurons increased and that of feeding center neurons significantly decreased after glucose was given intravenously. The spike aciivity pattem reversed in response to intravenous insulin injections. Oomura and associates (1964) also found, that spontaneous urit discharges of the ventromedial nucleus were affected by intravenous injections of giucose.

So it appears that the satiety center is activated by blood glucose levels in the body. There are other changes produced by feeding which may also stimulate these neurons. One possibility is that the specific dynamic action of focds may increase the heat stress of the body (Strominger and Brobeck, 1953). Another change which may stimulate hypothalamic neurons is the concentration of certain circulating metabolites influenced by fat, depots (Kennedy, 1953) and water concentration and its shifts among compartments of the body (Lepkorsky, Lyman, Flemming, Nagumo and Dimick, 1957). 
From these investigations by Anand and Oomura it is evident that the glucose ievel of the blood affects spike activity, even though there are several explanations of how this may take place. These studies do not explain how changes in spike activity in the ventromedial area are related to inhibition of feeding.

\section{GIucoreceptor Mechanism}

Fussek and Morganne (1963) questioned the fact that the signals provided by the blood are always channeled through the ventromedial area. Cats with ventromedial hypothalamic lesions were injected with glucose, and it was found that sensitivity to glucose does not differ from those animals not deprived of the ventromedial area. Russek and Morganne believe that these results provide ovidence for the existence of glucoreceptors outside the rentromedial area.

Intraperitoneal injections of glucose and normal saline were given to rats with electrolytic lesions in the ventromedial hypothalamus and to normal controls maintained on a $23 \frac{1}{2}$ hour deprivation schedule. Food intake was depressed even more in the hypothalamic hyperphagic rats than in the controls (Reynolds and Kimm, 1965). These researchers also believe that glucoreceptors could be located outside the ventromedial hypothaiamus. Another alternative offered by these researchers is one advanced by Kranse (1962). According to Kranse, electrical stimulation of the ventromedial hypothalamic region depresses food intake not as a primary effect on hunger, but as a general distracting or disrupting effect. Reynolds and Kim believe it is possible that the electrolytic lesions sensitize other nevral structures either through reiease from 
inhibition or by irritation. If these sensitized structures include some cells which are glucoreceptive, and if activation of these cells leads to some behavior incompatible with eating, the exaggerated effect would be explained.

These latter obsexvations question the role of the ventromedial hypothalamus in the regulation of food intake. Several investigators have recently suggested that the changes in food intake which are commonly seen following ventromedial damage might be secondary to hormonal effects and/or a general change in affect. Valenstein (1.969) has recently shown that the very pronounced hyperphagia-obesity syndrome can be seen only in the female of the species and appears to be attributable to hormonal mechanisms.

A closer look at the feeding behavior of the male rat with such lesions (Grossman, 1966) supgests that the relatively small charges in food intake in the male might be due to a general change in affect rather than influences specific to feeding behavior. Male rats with ventromedial lesions overeat only when the food is highly palatable and are hypophagic or even aphagic when the diet is made slightly unpleasant by adulteration with roughage or quinine. Even when the food is palatable, such animals do not work for food as well as nomal rats (Grossinan, 1966) and similar deficits become apparent when saccharin or quinine is added to the ventromedial animals' water supply or when these animals are required to work for water rewards (Corbit, 1965; Grossman, 1956).

It seems evident that electrolytic lesions in the ventromedial hypothalamus result in an animal's overeating and becoming obese. The 
manner in which hyperphagia comes about is not understood. It is possible that the lesions produce irritation, a homonal change, release of certain neurons from inhibition or a general change in affect. Some blood factor seems to effect food intake and evidence that it is glucose comes from: changes in the activity of neurons in the ventromedial hipothalamus as the blcod glucose level changes, influence of giucose on gastric contractions, and evidence that blood glucose levels rise at a time food intake is stopped. A more cleax understanding of the relationship between the chnages in neuronal activity in the ventromedial area as a result of changes in the blood glucose level and the manner in which the electrolytic lesions in the ventromedial area produce obesity is needed. The work of Reynolds and Kimm and Russek and Morganne offer evidence against the hypothesis that g.lucoreceptors are located in the veritromedial hypothalamus.

\section{Goldthioglucose Induced Obesjty}

During a toxological study of gold compounds, it was noted that a number of albino mice receiving goldthioglucose showed a marked increase in size. Subsequent experiments resulted in the finding that mice showed marked weight gains by a single injection of goldthioglucose (Waxler and Brecher, 1949).

Mayer and Marshall (1956) demonstrated that the injection of compounds in which the gold thiomoiety is linked to metabolites other than glucose (goldthiomalate, goldthiogalactose, goldthiosorisitol, goldglycerol) produced neither ventromedial damage nor obesity.

A direct demonstration of the special affinity of the ventromedial nuclei for goldthioglucose was provided when Marshall, Barnett and 
Mayer (1955) showed that in mice, injections of golathioglucose sufficient to produce obesity selectively destroy cella in this region. Liebelt and Perry (I957) confirmed these findings in experiments with several different strains of mice. It is believed that it is the affinity of the cells in the ventromedial area for glucose that leads them to take on the goldthioglucose.

Recently the specific affinity of the hypothalamic center for goldthioglucose was investigated by quantitative measurement and localization of the gold deposits in the brain (Debons, Silver, Cronkite, Jobnson, Brecher, Tenzer and Schwartz, 1962). The results indicated that the obese animals had a higher concentration of gold in the hypothalamic area than similarly injected animals that had not become obese. Accumulations of gold could be noted not only in the hypothalamic region, but also in other areas, confirming earlier evidence of extrahypothalamic lesions due to goldthioglucose (Perry and Liebelt, 1961 ). Brecher, Laqueur, Cronkite, Edelman and Schwartz (1965) investigated the goldthioglucose lesion in order to trace its entire development from a large initial necrotic lesion to a barely visible scar. They found that the ventromedial nucleus is not the center of the lesion since it is frequently situated only at the margin. The ventromedial nucleus may be largely spared in the presence of a clearmcut hypothalamic lesion produced by the goldthiogiucose. The more prominent scar in the obese animals correlates with the larger initial lesion necessaxy for complete bilateral destruction of the ventromedial nucleus which is known to be a prerequisite to hypothalamic obesity. 
Goldthioglucose seems unique among gold compounds in that it produces lesions in the ventromedial hypothalamus and other areas of the brain.

Of mice surviving a dose of goldthioglucose which is lethal to 50\% (ID 50) approximately 30\% become obese (Ifayer, 1954). The increase is due primaxily to an increase in adipose tissue (Waxler and Brecher, 1950). The weight gain reaches its peak between 1-15 weeks after injection with a total gain of about four times the original body weight (Mayer, 1960). In general there is a greater increase in weight when larger doses of goldthioglucose are administered. The toxic effect of goldthioglucose varies with the different strains of mice. For example, the mid-lethal dose for the $C_{58}$ strain is $.4 \mathrm{mg} / \mathrm{gram}$ body weight, whereas the mia-lethal dose for Balb/C mice is $1.5 \mathrm{mg} / \mathrm{gram}$ (Leibelt, Kaoru, Leibelt and Perry, 1.960).

Effort: to describe the goldthioglucose obese animal have resulted in the finding that obese mice eat more each time they eat but eat fewer meals than controls. No damage to the water intake regulatory mechanism was found (Friedman, Wayne and Janowitz, 1962).

Some researchers have investigated the relationship of the variation in blood glucose at the time of injection to the lesions produced by goldthioglucose. Comparison was made of the gold accumulation in the satiety center of goldthioglucose injected mice with that of diabetic mice which have a high blood glucose level. In this study (Debons, 1968) it was found that diabetes innibited the deposition of goid and the formation of lesions whereas the controls injected with golàthioglucose showed gold deposition and lesions. The insulin deficiency directly or through the effects of circulating metabolites 
decreases uptake of goldthioglucose by the satiety center. Likuski and colleagrues (1968) administered two glucose analogues at the same time that goldthioglucose was given. Among animals receiving this treatment, less obesity and less gold deposition at the site of the lesion was observed. Mice made diabetic and subsequently injected with goldthioglucose showed a decreased uptake of gold in the ventromedial hypothalamus. These researchers attributed their results to competition between the glucose inhibitor and goldthioglucose for the glucoreceptor sites.

The accumulation of gold in the hypothalamus and the development of hyperphagia and obesity were studied in mice given a single intravenous injection of goldthioglucose at various levels of blood glucose (Edelman, Schwartz, Cronkite, Brecher and Livingston, 1965). Glucose concentration at the time of the goldthioglucose injection was correlated directly with the level of goldthioglucose in the blood three minutes later, with the hypothalamic uptake of gold, with the extent of the hypothalamic lesion and with the severity of the subsequent hypexphagia and obesity. This finding that as the glucose concentration of the blood is increased, the severity of the reaction to the goldthioglucose increases is different from those of Likuski and Edelman. There is no obvious explanation for these opposing results but it is possible that cells respond differently to different types of glucose and so would take on more or less goldthioglucose depending upon the manner in which the glucose level of the blood was raised. Unlike electrolytically-induced ventromedial lesions, goldthioglucose-caused lesions seem to affect the food intake regulation with little impairment shown in other functions. Fox example, unlike mice 
made obese by electrolytic lesions, goldthioglucose obese mice do not show the usual: rage response, gonadal atrophy (they can mate and rear young) and disturbances in water balance (Anderson, 1953; Friedman, 1962; Ingram, 1952, 1956; Katsuki, Hevonto, Hotino, Ito, Ishimoto, Makino, Hososake, 1962; Mayer and Marshall, 1956; Montreul-Langlois, 1956). In sumary it might be said that goldthioglucose produces lesions in the ventromedial hypothalamus as well as in other areas of the brain. The level of obesity varies a great deal. Reasons for this variation are not completely understood but it seems to depend in part on the amount of goldthioglucose given, and the strain of mice used. The blood glucose level at the time of injection has been demonstrated to influence the uptake of gold, the extent of the lesion and the severity of the obesity, but the direction of this difference is not clear. Functions other than food intake are not affected by goldthioglucose. 
DESCRIPTION OF THE PROBLENI

Mayer (1953) has suggested that hunger occurs when glucose is not available for metabolic purpcses and that satiation supervenes when glucose is made available. According to Mayer, the control of this mechanism rests with the ventromedial glucoreceptors. If cells sensitive to blood glucose levels are destroyed by a goldthioglucose injection, food intake should no longer be affected by changes in the blcod glucose level. So the food intake of animals who have been made obese by a goldthioglucose injection should not change as blood glucose utilization changes.

The purpose of this investigation is to examine the effect of intraperitoneal injections of glucose on the food intake of nice who have been previously injected with goldthioglucose.

If the glucoreceptors in any area of the body are ciestroyed by the goldthioglucose it would be expected that food intake would not change with the blood glucose level. 
CHAPTER IV

METHOD

The Goldthioglucose Injection

The subjects were 120 female mice of the Swiss-Webster strain obtained from Simonsen Laboratory. The animals initial body weight was 20--2l grams.

It has been demonstrated that as the dosage of goldthioglucose is increased the drug is lethal to a larger proportion of the animals (Leibelt, Kaoru, Leibelt and Perry, 1960). In an effort to keep the experimental groups as nearly the same size as possible, a disproportionately large number of arimals were assigned to groups receiving the higher dosage levels.

At injection the subjects were separated into four groups: Group I, controls, receiving no treatment (19 animals); Group II given $.5 \mathrm{mg}$. of goldthioglucose per gram of body weight (25 animals); Group III given $1.0 \mathrm{mg}$. of goldthioglucose per gram of body weight (33 animals) and Group IV given $1.3 \mathrm{mg}$. of goldthioglucose per gram of body weight (40 animals).

The golathioglucose used was Solganol (Schering Corporation) and was administered by intraperitoneal injections from a solution containing $100 \mathrm{mg}$. of goldtrioglucose per cc of sesame oil.

All animals were fasted 24 hours prior to injection since this management reduces mortality without decreasing the incidence of obesity (Owens, Parsons and Crispell, 1953). 
Two to five inice were housed in each cage. The subjects were fed ad Iib food and water. The veight of the food intake pooled for all mice in each cage and the body weight of each animal was recorded weekly.

\section{Deprivation}

Fifty-seven days after being injected with goldthioglucose, the animals were put on a food deprivation schedule. This schedule was designed to allow the animals to adjust to getting their daily food intake during a 50 minute period. This was done by shortening the feeding periods in incremental steps from 90 minutes to 50 minutes. The fifty minute eating period was arrived at by way of observation that the animals could maintain between $80 \%$ and $91 \%$ of their predeprivation body weight by eating for 50 minutes a day. At the end of the deprivation period the mice vere eating once a day from $6: 15$ p.m. to $7: 05$ p.m.

\section{The Experimental Period}

The deprivation schedule was continued during the ten day experimental period. The mice were transferred to individual cages for this phase of the experiment so that individual food intake could be measured.

On the first day of the experimental period all animals were given an intraperitoneal injection of $0.3 \mathrm{ml}$ of normal saline containing $60 \mathrm{mg}$. of glucose (20 mg. per $\mathrm{ml}$. of normal saljne) 15 minutes before their daily feeding time. Prior to the feeding period the plastic cages were emptied of litter so that any scattered food could be collected after the feeding period to permit the total food consumption to be calcuiated. 
A similar procedure was followed on the second day with the exception that the injection given was $0.3 \mathrm{ml}$ of normal saline containing no glucose.

The procedures of the first two days were repeated on altermate days for the remainder of the 10 day period.

The mice were weighed following each feeding period. During this experimental period it became apparent that the animals could not maintain an adequate weight on this schedule. It is possible that the trauma of the injection was responsible for this. Supplementary food was provided prior to day four (saline), day five (glucose), day seven (glucose) and day eight (saline). On these days six grams of lab chow was given to each animal at 8:00 p.m. and the extra food, if not eaten by 10:00 a.m. the next day, was removed. Ihus on these days the animals were deprived for 8 hours and 15 minutes instead of 23 hours and 10 minutes.

Durine the ten day experimental period data was obtained for three days in each of the following conditions: glucose with no supplementary feeding and saline with no supplementary feeding and two days each of saline with supplementary feeding and glucose with supplementary feeding. To simplify the analysis, the data was reorganized. Data for the last two days, one a glucose injection and the other saline were not included. Individual food intake means were found for the remaining like conditions described above and these means were used for the analysis of variance.

Some research indicates that the more obese animals tend to have more extensive lesions with a higher concentration of gold than the nonobese animals (Brecher, Laqueur, Cronkite, Edelman, and Schwartz, 
1965; Debons, Silver, Cronkite, Johnson, Brecher, Lenzer and Schwartz, 1962). If larger lesions result in more damage to glucoreceptors, the food intake of the extremely obese animals would be affected less as the blood glucose level changes than that of the less obese or the controls. To investigate this possibility data for the animals in the experiment were regrouped accordine to body weight of the mice. The body weights for this regxouping were obtained two weeks after the end of the experimental period. During this two week period the animals were fed ad lib food and water. All animals which had received goldthioglucose and weighed more than the heaviest control were classified obese and divided in two groups: the moderately obese, weighing between 37 and 44 grams and the extremely obese weighing more than 44 grams. 


\section{CHAPTER V}

RESULTS

\section{THE GOL.DTHIOGLUCOSE IINJECTION}

Table I shows the number of animals surviving the goldthioglucose injection at each dosage level, the number who became obese, and the number of animals included in the experiment.

\section{TABLE I}

NUMPER OF EXPERTMENTAL AINTIALS

Mg. Goldthioglucose per gram Body Wojght

0 .5 1.0 1.3

Number of animals

in the group

19

25

33

40

Number nurviving foldthioglucose injection 25

11

4

Number of animals

in experiment

18

22

31

Total number of

obese animals

0

7

7

Mociexately Obese

0

1

Extremely Obese

0

3

6 
Inspection of Table I indicates that approximately one-thixa of those mice receiving .5 mg. of goldthioglucose per gram of body weight became obese and more than half of those in the $1.0 \mathrm{mg}$. per gram group became obese.

Data for one animal in Group I (controls) and three animals in Group II (.5 mg. per gram) were not used since these mice lost so much weight during the first two days of the experimental period that supplementary glucose injections had to be given. Since so few of the animals in Group IV (1.3 mg. per gram) survived the goldthioglucose injection data for this group were not included.

\section{THE EXPERIMENT}

With the animals grouped according" to the injection received, an analysis of variance for three factors with repeated measures on two factors was performed on the data (Weinex, 1962). The summary of this analysis is presented in Table II.

Inspection of Table II reveals that the dosage level of goldthioglucose given made no difference in the food intake of the mice under any condition of the experiment. This is incicated by the significant main effect for the glucose saline factor and the supplementary feeding factor in the absence of significant interaction effects. 
TABLE II

ANALYSIS OF VARTANCE

SUMMARY TABLE

\begin{tabular}{|c|c|c|c|c|}
\hline Source of Variation & $\begin{array}{l}\text { Sum of } \\
\text { Squares }\end{array}$ & d.f. & $\begin{array}{l}\text { Mean } \\
\text { Square }\end{array}$ & $\mathrm{F}$ \\
\hline Between Subjects & - & 50 & & \\
\hline A. Golảthioglucose & 3.4732 & 2 & 1.7366 & - \\
\hline Exxor (a) & .870 .5661 & 48 & 18.1368 & - \\
\hline Within Subjects & & 153 & & \\
\hline B. Giucose, Saline & 11.2774 & 1 & 11.2774 & $42.2375^{*}$ \\
\hline $\begin{array}{l}\text { AB. Goldthioglucose } \\
\text { and glucose, saline }\end{array}$ & .4724 & 2 & .2362 & - \\
\hline Error (b) & 12.8164 & 48 & .2670 & - \\
\hline C. Supplementary food & 7.7762 & 1 & 7.7762 & $24.4075^{*}$ \\
\hline $\begin{array}{l}\text { AC. Gold thioglucose } \\
\text { and sup. food }\end{array}$ & .4491 & 2 & .2245 & - \\
\hline Error (c) & 15.2932 & 48 & .3186 & - \\
\hline $\begin{array}{l}\text { BC. Glucose, Saline and } \\
\text { sup. food }\end{array}$ & .6822 & 1 & .6822 & $11.7823 *$ \\
\hline $\begin{array}{l}\text { ABC. Goldthioglucose; } \\
\text { glucose and saline } \\
\text { and sup. freding }\end{array}$ & .2082 & 2 & .1041 & 1.7979 \\
\hline Error $(b c)$ & 2.7802 & 48 & .0579 & - \\
\hline$* \mathrm{p} \quad .00 \mathrm{z}$ & & & & \\
\hline
\end{tabular}


It can be seen, however, that for all levels of the goldthioglucose injection the animals food intake was different when they were given glucose than when they were given saline.

This is indicated by the absence of a significant main effect and of an interaction for the goldthioglucose factor and the presence of a main effect for the glucose saline factor.

The analysis also reveals that providing supplementary food resulted in a difference in food intake which was consistent among other factors.

A significant interaction was observed between the glucose factor and the supplementary feeding factor. It can be seen by examining the table of means (Table III) that the difference in food intake between days in which glucose was given and days in which saline was given was greater when supplementary food was offered than when it was not.

The table of means (Table IIT) shows that at all levels of obesity, the mean food intake for the mice was less when they were given a glucose injection than when they were given saline. 
TABLE III

MEAN FOOD INTAKE IN GRAMS BASED UPON THE DOSAGE IEVVEL OF GOLDSHIOGLITCOSE

Goldthioglucose

Injection

Supplementary Food

No Supplementary Food

Food Intake in Grams Food Intake in Grans

GIucose

Saline Glucose

Saline

Group I

Controls

$\begin{array}{lllll}(\text { no injection }) & 1.46 & 1.92 & 2.02 & 2.32\end{array}$

Group II

.5 mg. per gm.

1.77

2.31

2.27

2.68

Group III

$2.0 \mathrm{mg}$. per gm.

I. 48

2.32

1.96

2.36

It can also be seen that the mean food intake was less on days when supplementary food was given than when it was not.

Table IV shows the mean food intake based on the regrouping of the animals according to their level of obesity.

\section{TABLE IV}

MEAN FOOD INTAKE IN GRAMS BASED UPON THE LEVEL OF OBESITY

Level of Obesity Supplementary Food No Supplementary Food Number Glucose Saline Glucose Saline of Mice

\begin{tabular}{llllll}
$\begin{array}{c}\text { Controls } \\
\text { (Not Obese) }\end{array}$ & 1.46 & 1.92 & 2.02 & 2.32 & 19 \\
$\begin{array}{c}.5 \mathrm{mg} \text {. per gm. } \\
\text { (Not Obese) }\end{array}$ & 1.72 & 2.27 & 2.19 & 2.55 & 15 \\
$\begin{array}{c}1.0 \mathrm{mg} \text {. per gm. } \\
\text { (Not Obese) }\end{array}$ & 1.32 & 2.24 & 2.90 & 2.54 & 5 \\
$\begin{array}{c}\text { Moderately Obese } \\
\text { Extremely Obese }\end{array}$ & 2.18 & 2.76 & 2.49 & 2.90 & 5 \\
\hline
\end{tabular}


Food intake of animals given a glucose injection seems to be less at a.ll levels of obeaity than when they were given saline. The extent of giucose-saline difference appears to be similar in all conditions. It also appears that food intake is less when the subjects were given supplementary food than when they were not.

A comparison of Table III with Table IV reveals that there is no striking difference in food intake between animals grouped according to the goldthioglucose dosage given and those grouped according to the level of obesity reached. So, the level of obesity reached by an animal does not seem to influence his food intake under the conditions of this experiment. 
CHAPTITR VI

DISCUSSION

According to Jean Mayer "...the regulation of food intake is dependent or ventromedial nucleus glucoreceptors which can be destroyed by golathioglucose." (1968, p. 1345). Mayer has also said that the receptors "...have a special affinity for glucose and are activated by this netabolite in the measure that they utijize it." (1967, p. 331). If these receptors in an animal are destroyed by goldthioglucose the animal should no longer respond to a change in blood glucose utilizam tion by varying food intake.

A test of Mayer's idea that glucoreceptors in the ventromedial area respond to blood glucose utilization was made by Reynolds and Kimm (1965) using rats and by Russei and Morganne (1963) using cats. Both of these experiments involved the destruction of the ventromedial hypothalarus with bilateral electrolytic lesions. The lesions were of the same type as those which produce the hypothalamic hyperphagia synarome described earlier in this paper (see page 4). In both cases the food intake of the hypothalamic hyperphagic animals was depressed after the animals had been given a glucose injection. If the glucoreceptors in the hypothalamic hyperphagic animals had been destroyed food intake should not have been depressed by the flucose injection. In both studies, Russek and Morganne (2963) and Reyrolds and Kirm (1965) explained their findings by saying that glucoreceptors 
might be located outside the ventromedial hypothalamic area destroyed by the electrolytic lesjons.

The goldthioglucose-induced lesions differ from those produced electrolytically in that the lesions are not necessarily restricted to one area of the brain and they seem to produce no behaviorai change other than food intake. Except that the lesions were produced in a different mannex the procedure repoxted here is similar to that of Reynolds and Kimm (1965). The results are similar to those of both Reynolds and Kimm and Russek and Morganne (1963). That is, goldthioglucose treated animals reduce their food intake as much as do normal animals, when given a glucose injection prior to feeding. While the goldthioglucose induced lesions differ from electrolytic lesions in several respects neither lesion seens to effect the animals' ability to respond to blood glucose level changes by altering food intake.

It would be expected, from Mayer's description of the glucoreceptors, that the destruction of these receptors by the goldthioglucose should cause some difference in food intake between the lesioned animals and the controls after glucose injections. Clearly no difference was observed so it might be concluded that (I) glucoreceptors do not exist or (2) that the mechanism by which these cells operate is more complex than has previously been postulated.

An explanation of the resalts of this experiment might be that the glucoreceptors were destroyed by the goldthiogiucose lesions and the decreased food intake among all the animals after a glucose injection could be the result of discomfort or illness felt by the animals as a result of a sudien rise in the glucose level. This 
explanation is questionable because on dajs in which the animais had been fed supplementary food prior to their daily feeding period they would eat less than when supplementary food had not been provided. There is no reason to believe that the discomfort or illness would have been different on days when the animals were fed supplementary food than when they were not.

A tenable explanation of the results of this experiment can be based on an idea advanced recently by Grossman (I968). He has stated that the changes which are commonly seen following ventromedial damage might be secondary to hormonal effects and/or a general change in affect. Thus, in the present study, the goldthioglucose lesions might produce such a change which would result in the animal becoming obese. This could leave the mechanism which is sensitive to the blood glvcose level intact and the animal could still respond to a rise in the glucose level by decreased food intake. This explanation also leaves some unanswered questions. Why does goldthioglucose and no other gold compound tested result in the lesion and subsequent obesity? How does the presence of glucose in the blood at the time of the goldthioglucose injection change the gold uptake and the extent of the lesion?

It is possible to explain the resuits of the present experiment by positing a mechanism by which the glucoreceptors operate. Cells in such a mechanism might be differentially sensitive to various levels of glucose.

Activity of the individual neurons within the system would increase in relation to the presence of that level of glucose. As a threshold of neuronal activity is reached food intare is stopped. 
When goldthioglucose is administered, cells sensitive to that particular level of g]ucose are destroyed. So part of the glucoreceptor system is gone and these cells cannot contribute to the threshold. For a threshold now to be reached the remaining cells must be more actire. This activity can increase only if that level of glucose increases. In an ad lib feeding situation the goldthioglucose injected animal. becomes obese because he must eat more food in order for the remaining cells in the system to increase their activity enough to reach a threshold and stop food intake.

The size of the glucose injection used during the experimental period in this study could have increased the activity of those glucoreceptors which were not destroyed enough to reach a threshold and stop food intake anong the goldthioglucose obese animals as well as the controls.

The interaction observed between the supplementary food and the saline glucose factor can also be explained by postulating a threshold for stopping food intake. The difference in food intake between days in which glucose was given and days in wich saline was given was greater when supplementaxy food was offered than when it was not. It is possible that on the days when saline was given and no supplementary food provided the threshold for stopping food intake was not reached at all during the 50 minute feeding period. Thus the animals receiving saline and no supplementary food had not reached a threshold at which food intake would stop at the end of the eating period. 
It is possible to test this idea by using a design similar to the one reported here with the exception that several types of glucose would be used during the experimental period instead of just one.

No matter what explanation is offered for the results of this experiment it is clear that Mayer's idea that the glucoreceptors, as described by him, are destroyed by goldthioglucose has not been supported by this study. 


\section{BIBLIOGRAPHY}

Adolph, E. F. "Urges to Eat and Drink in Rats," American Joumal of Physiology, 1947, 151, 110.

Anand, B. K. "Regulation of Food Intake," American Joumal of Clinical Nutrition, $1960,8,529$.

Anand, B. K. "Nervous Regulation of Food Intake," Physiolorical Reviek, $1961,41,677-707$.

Anand, B. K., Dra, S., and Schoenberg, K. "Hypothalamic Control of Food Intake in Cats and Monkeys," Journal of Physiology, 1951, 127, 143-152.

Anand, B. K., and Brobeck, J. R. "Hypothalamic Control of Food Intake," Yale Journal of Biology and Medicine, 1952, 24, 123-3.39.

Anand, B. Ko, Chinna, C. S., Sharmee, K. N., Drua, S. and Singh, B. "Activity of Single Neurons in the Hypothalamic Feeding Centers -. The Effect of Glucose," American Joumnal of Physiology, 1964, 207, $1146-1154$.

Andersson, 33., and Larsson, B. "Influence of Local Temperature Changes in the Pre-optic Area and Rostral Hypothalamus on the Regulation of Food and Water Intake," Acta Physiology Scandanavia, 1961, $52,75-89$.

Anliker, J., and Mayer, J. "Bar Pressing in Rats with Ventromedial Hypothalamic Lesions," American Journal of Clinical Nutrition, $1957,5,148$.

Bach, I. M. M., O?Brian, C. P., and Cooper, G. P. "Some Observations Concerning the Hypothalamic Regulation of Growth and Food Intake," Progress in Brain Research, 1957, 5, 114.

Bailey, P., and Bremmer, E. "Relation of Diabetes Insipedus to the Hypothalmus," Endocrinology, 1921, 5, 761.

Brechex, G., Laquewr, G. L., Cronkite, E. P., Edelman, P. M., and Schwartz, I. L. "The Brain Lesion of Goldthioglucose Obesity," Journal of Experimental Medicine, 1965, 121, 395-401.

Brobeck, J. R. "Neural Regulation of Food Intake," Annals of the New York Academy of Science, 1955, 1, 44-55.

Brobeck, J. R. "Neural Control of Hunger, Appetite and Satiety," Yale Journal of Biology and Medicine, 1957, 29, 565-574.

Brobeck, J. $\mathrm{K}$, "Food̃ and Temperature," Recent Progress in Hormone Research, 1960, 16, 439-466. 
Brobeck, J. R., Tepperman, J., and Long, C. N. "Experimental Hypothalamic Iyperphagia in the Albino Rat," Yale Joumal of Biology and Medicine, 1943, 15, 831-853.

Cannor, W. B., and Washburn, A. I. "An Explanation of Hunger," American Joumal of Physiology, 1912, 29, 441-454.

Carlson, A. J. The Control of Hunger in Health and Disease. Chicago, University of Chicago Press, 1916.

Coons, E. F., Levak, M., and Miller, N. E. "Lateral Hypothalamic Leaming of Food Seeking Response Motivated by Electrical Stimulation," Science, 1.965, 150, 1320-1321.

Corbit, J. D. "Hyperphagic Hyperreactivity to Adulteration of Drinking Water with Quinine and $\mathrm{H} \mathrm{Cl}$ " Jourmal of Comparative Physiological Psychology, 1965, 60, 123-124.

Davis, J. D., and Miller, N. E. "Food Intake Controlled by a Blood Factor," Science, 1967, 156, 47-82.

Debons, A. F., Silver, I., Cronkite, E. P., Johnson, H. A., Brecher, G., Lenzer, P., and Schwartz, J. L. "Localization of Gold in the Movse Brain in Relation to Goldthioglucose Obesity," American Journal of Physiolosy, 1962, 202, 743-750.

Debons, A. F., Silver, I., Cronkite, E. P., Johnson, H. A., Brecher, G., Lenzer, P., and Schwartz, J. I. "Goldthioglucose Damage to the Satiety Center: Inhibition in Diabetes," American Journal of Physiology, 1968, i'i4, 652-658.

Delgado, J. N., and Anand, B. K. "Increase of Food Intake by Electrical Stimulation of the Lateral Hypothalamus," American Journal of Physiology, 1953, 172, 162-168.

Deutsch, J, A. The Structural Basis of Behavior, Chicago, University of Chicago Press, 1960.

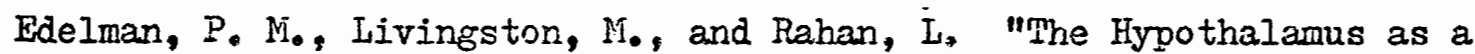
Sensing Center: A Study of Glucose in Coldthioglucose Obese Mice," Federation Proceedings, 1964, 23, 304.

Fink, R. P. and Heimer, I. "Two Methods for Selective Silver Impregnation of Degenerating Axons and. Their Synaptic Endings in the Central Nervous System," Brain Research, 1967, 4, 369-374.

Friedman, G., Waye, J. D. and Janowitz, H. D. "Relationship of Food and Water Intake in Aurothioglucose Obesity," American Journal of Physiology, 1962, 203, 631.

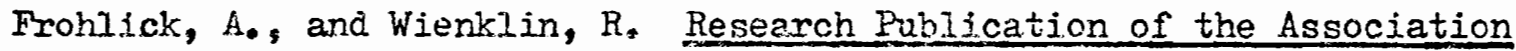
of Nerve and Mental Disorders, 1948, 20, 16-28. 
Grossman, S. P. "Hypothalamjc and Limbic Influences of Food Intake," Federation Proceedings, 1968, 27, 6, 1349-1359.

Grossman, M. I., and Stein, I. F. "Vagotomy and the Hunger Producing Action of Insulin in Man," Jourmal of Applied Physiology, $1948,1,263-269$.

Grossman, S. P. and Grossman, L. "Effects of Chemical Stimulation of the Midbrain Reticular Formation on Appetitive Behavior," Joumal of Comparative Physiological Psychology, 1966, 61, $325-332$.

Hoebell, B. "Inhibition and Disinhibition of Self Stimulation and Feeding: Hypothalamic Control of Post Irgestional Factors," Joumal of Comparative and Physiological Psychology, 1968, $66,89-100$.

Ingran, W. R. "Brain Stem Mechanisms of Behavior," Electroencephalography and Clinical Neurophysiology, 1952, 4, 397-405.

Katsuki, S., Hevanta, Y., Horino, M., Ito, M., Ishimoto, M., llakino, N. and Hososako, A. "Obesity and Hyperglycemia Induced in Mice by Goldthioglucose," Diabetes, 1962, I1, 209-215.

Kennedy, G. C. "The Role of Depot Fat in the Hypothalamic Control of Food Intake in the Rat," Proceedinga of the Royal Society of London, Series B, 1953, 140, 578-592.

Kennedy, G. C. "Food Intake, Energy Balance and Growth," British Medical Bulletin, 1966, 22, 216-220.

Kranse, F. B. "General Disruption Resulting from Electrical Stimulation of the Ventromedial Hypothalamus," Science, 1962, 138, 822-823.

Leibelt, R., Kaoru, S., Leibelt, A. G., and Perry, J. "Genetic Susceptibility to Goldthioglucose Induced Obesity in Mice," Proceedings of the Society of Experimental Biology and Medicine, $1960,104,689-692$.

Leibelt, R., and Perry, J. "Hypothalamic Lesions Associated with Goldthioglucose Induced Obesity," Proceedings of the Society of Experimental Biology and Medicine, 1957, 101, 774-777.

Likuski, H. J., Debons, A. F., and Cloutier, R. J. "Inhibition of Goldthioglucose Induced Hypothalamic Obesity by GIucose Analogues," American Joumal of Physiology, 1968, 212, 669-676.

Lepkorsky, $S_{*}$, Lyman, $R_{*}$, Flemming, P., Hagumo, M., and Dimick, M. M. "Gastrointestinal Regulation of Water and Its Effect on Food Intake and Rate of Digestion," Ainerican Joumal of Physiology, 1957, 187, 327-331. 
Marshall, N. B., Barmett, D., and Hayer, Jo "Hypothalamic Lesions in Goldthioglucose Injected litce," Proceedings of the Society of Experimental Biology and Medicins, $1955,90,240$.

Mayer, J. "A Glucostatic Niechanism for the Regulation of Food Intake," Hew England Journal of Medicine, 1953, 249, 13-16.

Mayer, J. "The Obese Hyperglycemic Syndrome of Mice as an Example of Metabolic Obesity," American Joumal of Clinical Nutrition, $1960,8,712$.

Mayer, J. "The Ventromedial Glucostatic Mechanism as a Component of Satiety," Postgraduate Medicine, 1965, 38, Al01-108.

Mayer, J., and Arees, E. A. "The Ventromedial Glucoreceptor System," Federation Proceedings, 1968, 27, 1345-1348.

Mayer, J., and Marshall, N. B.' "Specificity of Goldthioglucose for Ventromedial Hypothalamic Lesions and Hyperphagia," Nature, $1956,178,1399$.

Mayer, J., and Thomas, Do W. "Regulation of Food Intake and Obesity," Science, 1967, 156, 328-337.

Mayex, J., and Zeghera, C. Y. "The Multiple Etiology of Obesity: Production of Two Iypes of Obesity in Isittermate Mice," Science, $1954,119,96$.

Miller, $\mathrm{H}_{0} \mathrm{E}_{\bullet}$, Bailey, C. J., and Stevenson, J. A. E. "Decreased Hunger but Increasid Frood Intake Resulting from Hypothalamic Lesions," Science, 1950, 112, 256-259.

Montreul-Ianglois, A, "Obesite Produile par Aurothioglucose Shez la Souris XVII Femelle," Compl. Rend. Soc. Biol., 1956, 150, 4.

Murphy, J. "Inhibitory Neurons in the Ventromedial Nucleus of the Hypothalmas," Brain Research, 1968, July, 9358-9359.

Oomura, $Y_{\bullet}$ Bimura, H., Ooyama, T., Naino, $K_{\bullet}$, Ike, M., and Kuniyoshi, I. "Reciprocal Activities of the Ventromedial and Lateral Hypothalamic Areas of Cats," Science, 1964, 143, 484-485.

Owen, J. A. Jr., Parson, W., and Crispell, K. K. "Effects of Dietary Dilution on Food Intake in Goldthioglucose Lesioned Mice," Metabolism, 1953, 2, 262.

Perxy, J. H., and Leibelt, R. A. "Extrahypothalamic Lesions Associated with Goldthioglucose Induced Obesity," Proceedings of the Society of Experimental Biology and Medicine, 1961, 106, 55-57. 
Rabin, B. "The Effect of Lesions of the Ventromedial Hypothalnas on the Electrical Activity of the Ventrolateral Hypothalmas, "Electroencephalography and Clinical Neurophysiolosy, 1968, 25, 344-350.

Reynolds, W. R. "Ventrcmedial Lesions Without Hyperphagia," American Journal of Physiology, 1963, 204, 60-62.

Reynoids, W. R. "An Irritative Hypothesis Concerning the Regulation of Food Intake," Psychological Review, 1965, 72, 105-109.

Reynolds, W. R. and Kimm, J. "The Effect of Glucose on Food Intake in Hypothalamic Hyperphagic Rats," Journal of Comparative Physiological Psychology, 1965, 60, 437-440.

Russek, M., and Morganne, P. J. "Anorexic Effect of Intraperitoneal Glucose in the Hypothalamic Cat," Nature, 1963, 199, 1004-1005.

Sterfens, A. B. "Blood Glucose Levels and Food Intake in Normal and Hypothalamic Hyperphagic Rats," Acta Physiologica Pharmacologia Neerlandica, 1967, 14, 524-526.

Strominger, J. I., and Brobeck, J. R. "A Mechanism of Regulation of Food Intake," Yale Joumal of Biology and Medicine, I953, 25 383-390.

Stunkard, A. J., Von Itallie, J. B., and Reiss, B. B. "The Effect of Glucogen on Gastric Hunger Contractions," Proceedings of the Society of Experimental Biolory, 1955, 89, 250 .

Teitelbaum, P. "Sensory Control of Hyperphagia," Jouraal of Comparative ynsiologx, $1955,48,156-63$.

Teitelbaum, P., and Epstein, A. N. "Role of Taste and Smell in Regulation of Food and Water Intake," In Y. Zotterman (ed.)

Olfaction and Taste, New York, New York: Pergamon Press, 1963,

- $347-356$.

Teitelbaum, P., and Epstein, A. N. "The Lateral Hypothalamic Syndrome," Psychological Review, 1962, 69, 74-90.

Valenstein, E. S., Cox, V. C., and Kakolewsti., J. W. "Sex Differences in Hyperphagia and Body Weight following Fypothalamic Damage," Annals of the New York Academy of Science, 1969, 157, 1030-1048.

Waxler, S. W., and Brecher, G. "Obesity in Albino Mice due to a Single Injection of Goldthioglucose," Proceedings of the Society for Bxperimental Bioiosy and Medicine, 1949, 70, 498. 
Waxier, S. Wo, and Brecher, G. "Obesity and Food Requixements in Albino Mice following the Administration of Goldthioglucose," American Joumal of Physiology, 1950, 162, 428.

Winer, B. J. Statistical Principles in Experimental Design. New York, McGraw-Hi.ll Book Company, 1962. 